\title{
Essay og system
}

\author{
Mads Rosendahl Thomsen
}

I

Det essayistiske opfattes oftest i modsætning til det systemiske. Der er på den ene side det hierarkiserende system og på den anden det centrumsløse essay. Systemets vilje til helhed stilles over for essayets sans for detaljen. Det essayistiske er frihed og bevægelighed, mens systemet er tvang og stivhed.

På den baggrund kan det være overraskende, at en lærd læser som Karl Heinz Bohrer har udtalt, at han opfatter den tyske sociolog og systemteoretiker Niklas Luhmann som en af de sidste store tyske essayister. Hvis man ser på Luhmanns forfatterskab i forhold til essayet opstår der nogle interessante perspektiver til belysning af begge dele, både essayet og systemteorien. Ved at gå i systemets lejr gives der nogle svar på, hvorfor man skriver essayistisk, og hvordan Luhmann forbinder essayistisk udtryksform med viljen til systemisk tænkning.

Det er uheldigt at sætte system og essay som modsætninger. Der gives beskrivelser af forholdet mellem disse svævende størrelser, der snarere ser dem som indfoldet $i$ hinanden, og som måske også kan give en bedre forståelse af, hvad det er, den essayistiske modus er i stand til at gøre.

\section{II}

Siden midten af 6o'erne, hvor Luhmann for alvor begyndte at skrive, har han publiceret mere end 50 bøger og 500 kortere tekster - for nu at undgå at kalde dem artikler og essays uden nærmere overvejelser. De kortere afhandlinger har ofte karakter af klassiske essays, der undersøger et problem eller et begreb, og har som sådan deres egen selvstændige ret og afsluttethed. Men de fungerer samtidig som forsøg på at lave korrektur til den større teori, som Luhmann til stadighed udvikler, og som synliggøres i teksterne gennem et utal af krydsreferencer. Han taler selv om, at man ikke bør afvise, at essayets undersøgelse af begreber kan have ambitioner om at bidrage til en større konstruktion. Dette er måske en provokation over for en udbredt opfattelse af essayet som en tekst, der skaber sin egen helhed af monadisk og ureducérbar karakter.

Luhmann påpeger selv to måder, hvorpå essay og teorikompleks fungerer $\mathrm{i}$ forhold til hinanden. Essayet er på den ene side en form, der kan bruges til at afprøve enkeltdele $\mathrm{i}$ teorien, for at se om de holder, om det er frugtbart, om det burde være anderledes. På den anden side opfatter han essayet som en forlegenhedsform, der implicit fordrer at de udviklede begreber kan indarbejdes i teorisammenhænge. Om end disse måske kun er hypotetiske og kontingente (Luhmann 1987: 93-97).

Dette stiller på ny spørgsmålet om, hvad essayet er og skal være forbundet med? Skal det udgøre en flosset helhed, eller må det kunne anskues på baggrund af noget større? Der er patetiske bevægelser i begge valg. Både i påstanden om, at det ikke er sig selv nok, men i ligeså høj grad i afvisningen af, at det ikke må pege for eksplicit ud over sig selv og derved stå ved sine forudsætninger. Disse bliver så meget mere interessante, når der bringes en manifest redundans med $i$ anvendelsen af begreberne og tankefigurerne, som det sker hos Luhmann; og ikke den skjulte redundans, som man finder hos så mange andre.

Forholdet mellem variation og redundans er ikke uden grund et af de store temaer hos Luhmann. Dette gælder både $\mathrm{i}$ forhold til tænkningen af det sociale, hvor sociologiens opgave må være at finde mønstre af gentagelser uden at miste blikket for det partikulæres ret. Men det gælder også i teorier om 
æstetik, hvor man kan hæfte sig ved, at kunsten mere og mere er overladt til skabe sine egne fornødne gentagelser, idet der ikke blot kan henvises til traditionen. Mening må skabes med henvisning til systemet selv (Luhmann 1996: 513). Ligesom et kunstværk internt må opbygge mønstre og kompleksitet $i$ et spil mellem redundans og variation. Dette forhold er netop også, hvad der kendetegner ornamentet. Og essayet må bygge sine egne forudsætninger op ved at indføre distinktioner og iagttagelser, som gives værdi.

\section{III}

Luhmanns stil er på flere måder essayistisk. Man hæfter sig ved de kun tilsyneladende konkluderende afsluminger $\mathrm{i}$ både de store og små afhandlinger. Mens den videnskabelige artikel bygger op til en konklusion, er essayets problem at lave en ikke-slutning, der er prægnant uden at reducere alt det foregående til forstudier for konklusionens essens. Dette træk arbejder Luhmann ganske varieret med. Det sker i form af den pludselige afbrudthed, ved at pege på nye spørgsmål affødt af essayet, eller ved at lave en paradoksal og overraskende afvisning af de foregående overvejelser.

Et andet essayistisk træk ved Luhmanns tekster er, at de indarbejder en umådelig mængde af digressioner, der har megen humor gennem henvisninger til ofte obskure eksempler. Min egen favorit er fra Soziale Systeme, hvor en længere overvejelse over skriftens betydning for samfundets stabilitet underbygges af en note om, hvordan Luhmann forsøgte at forhandle om prisen på et stykke chokolade $i$ en slikbutik. I stedet for at svare pegede ekspedienten blot gentagne gange på prisskiltet, og sociologen fra Bielefeld havde gjort sig en empirisk erfaring (Luhmann 1984: 583). Men der er også ironi i digressionerne, fordi man ikke altid er klar over, om det er i en videnskabelig modus, at der henvises til en obskur bog fra den italienske renæssance, eller om det blot er et udtryk for den Lust am Text, der skinner igennem i Luhmanns skriverier.

Man kan også hæfte sig ved, at nogle begreber hos Luhmann bruges med henvisning til andre skrifter og diskuteres grundigt, mens andre kastes mere løst ind. Der opstår en konfliktfyldt facon mellem videnskabelig forpligtethed og essayistisk uforpligtethed. Selv siger Luhmann $\mathrm{i}$ et interview, at han ikke skelner skarpt mellem den videnskabelige artikel og essayet. Han ynder i noter at henvise til „parasit“ som Serres definerer det i „Le Parasite“ eller „frame“ som Goffman bruger det i „Frame Analysis“. Ganske komplekse begreber, emner for to store bøger, som der blot refereres til med en henkastet gestus.

IV

Det er dog ikke blot stilistisk, at man kan udpege fællestræk mellem Luhmanns systemteori og det essayistiske, men også i forhold til den motivering, der ligger bag udtryksformerne og teoridannelsen. Som udgangspunkt handler det som i så meget andet om at finde sprog til at tale om verden med. Men dette er på ingen måde ukompliceret, for ellers kunne man jo bare sige tingene som de er, og resten ville være ornamental udsmykning og retorik som skønmaleri.

Et af problemerne med sproget er, at det lader som om verden består af ting og entiteter, selvom det meste af det, som er interessant at tale om, er relationer, ytringer, begivenheder, handlinger og meget andet, som ikke er ting. Luhmann betegner dette forhold med „tingsskemaet“, som sproget (sproget!) organiserer sig efter. At tale om essayets genstand er allerede en fælde. Hvor finder man kærligheden?

Verden er ikke en samling af ting, snarere betingelsen for, at vi kan skelne, bruge distinktioner; eller slet og ret iagttage. Forestillingen om verden er dét blinde punkt, som må være tilstede i enhver observation. Denne „af-tingsliggørelse“ af forestillingen om verden henfører Luhmann til Kant (Luhmann 1996: 517). Men i romantikken slog denne vending over i subjektivitet og en overbebyrdelse af individet.

Hermed er de to værste aspekter ved sproget, som Luhmann udtrykker det i Soziale Systeme, markeret med tænkningen i entiteter på ene side, og verbernes tvangsmæssige tilskrivning af et subjekt bag enhver handling på den anden (Luhmann 1984: 
II5). Både essayet og systemteorien kan ses som forsøg på at finde en måde at komme ud over dette.

Et beslægtet problem er, at sproget leder os til at søge substantielle forklaringer. Man kommer alt for let til at spørge om hvad et essay $e r$, som om det var en ting med en essens. Man burde hellere spørge, hvordan et essay fungerer. Med Ernst Cassirers terminologi udtrykker det en bevægelse fra substantielle til funktionelle eller relationelle begreber. En overgang som både Luhmann og den franske sociolog Pierre Bourdieu vedholdende taler for (Luhmann I992: 48; Bourdieu 1997: 18).

Cassirers kritik er også en kritik af opfattelsen af verden som ting. Verden som historisk realitet er en levende proces, og det samme gælder for mennesket. Ved at afvise tingsskemaet afvises også det, der for Cassirer står som det grundlæggende for metafysik, nemlig begreberne om tingen og om kausaliteten (Krois 1984: 63-65).

Den substantialistiske måde at tænke på er den sunde fornufts måde, som Bourdieu udtrykker det, men denne tidligere besungne størrelse har det vanskeligt $i$ en omskiftelig verden fyldt med tilsyneladende paradokser. Problemer og temaer må anskues som bestemt af de relationer, de sættes i forhold til, og ikke som noget, der kan betragtes i sig selv. Tænkningen af det processuelle er vanskeligt, hvis man holder fast $\mathrm{i}$ substanser, og $\mathrm{i}$ tingsbegrebet frem for relationsbegrebet, som Cassirer påpeger, at det har været tilfældet gennem metafysikkens historie (Cassirer 1923: I0-II)

Essayet som form markerer en kontrakt mellem forfatter og læser omkring en retorik, der sidestiller substantielle definitioner. For sproget lader os ikke slippe uden om at sige eller skrive ting som „essayet er.“ Men hvis der siges „essayet er“ et utal gange $i$ en tekst, så nytter det ikke at prøve at finde den rigtige definition og udelukke resten. Excessen af definitioner fører til en paradoksal overgang. Det hele må tages med i læsningen, uanset at disse parataktisk opstillede forsøg på definitioner kan være overlappende eller modstridende. I denne proces tvinges man til refleksion over forholdet mellem disse, der kan aftegne mere komplekse forhold uden at ende $\mathrm{i}$ trangen til substantiel reduktion. Den interageren, der opstår i essayet, er det væsentlige.

Essayet er således en modus, der forsøger at sætte sig ud over sprogets tingsskema. En anden strategi til dette kunne være at forsøge at ændre sproget, så det passede bedre til vores oplevelse af virkeligheden. Men historisk viser det sig, at alle forsøg på at lave helt nye ord, der i sig selv skulle have anderledes egenskaber, er mislykkedes. Vi har det sprog, som vi har. Derfor forsøger Luhmann heller ikke på at ændre sproget, men bestræber sig i stedet på at skrive på en måde, så der kompenseres for dette: at give forståelse for det tidslige, det relationelle og ikke blot det tingslige. En række begreber indføres fra et bredt felt af videnskaber som biologi, sociologi, matematik, filosofi etc. Der skabes en veritabel bricolage med overførelser og tilpasning af begreber. Men brugen af systemteoriens begreber sker i Luhmanns værk på baggrund af den litteratur, der måtte findes inden for det felt, der undersøges, hvad enten det er litteraturkritik, jura eller økologi.

V

Et andet fællestræk mellem det essayistiske og Luhmanns systemteori ligger $i$ organiseringen af begreberne. Disse peger hverken mod en solid grund eller en bestemmende top, men kan kombineres på kryds og tværs. Det første hovedværk Soziale $S y$ steme er her paradigmatisk, idet det i forordet gøres klart, at bogen på sin vis er cirkulær, da man kan begynde $i$ et hvilket som helst kapitel, men dog må læse sekventielt derfra (Luhmann 1984: 14).

Som et betydningsfuldt kuriosum må nævnes Luhmanns berømte seddelkassesystem, som han bruger til at holde rede på sine ideer og tanker gennem et utal af kartotekskort. Dette arkiv, som han påbegyndte, da han var i midten af tyverne og ung jurist med et behov for at skrive nogle tanker ned, er ikke organiseret hierarkisk. Snarere er det en labyrint, hvor flanøren kan bevæge sig og opdage nye forbindelser. Sedlerne er nummererede og giver henvisninger til hinanden, men der gives ikke noget centrum og ikke nogen slutning. Men hvordan skulle det kunne være anderledes, når samfundet 
beskrives på samme måde - uden centrum og med en uforudsigelig fremtid?

Der gives flere lange lister over hvilke begreber, der er mest centrale hos Luhmann. Et kontingent udvalg kunne lyde: autopoiesis, mening, tid, paradoks, iagttagelse, egenværdi, medium/form, kompleksitet, kontingens, system, omverden, selvreference, differentiering etc. Komplekset af begreber giver kontinuitet i Luhmanns skriven, samtidig med at der foregår en stadig udvikling af begreber. Nye føjes til og andre mister betydning eller glider helt ud.

Der vil altid være kernebegreber hos essayister, der gives redundans og som er vanskelige at diskutere med, men må tages for gode varer inden for sammenhængen. Systemteorien er blevet essayistisk i sin grundholdning uden at give afkald på den gentagne anvendelse af begreber, der defineres med en vis fasthed uden at man ser bort fra deres kontingente oprindelse. Essay og system mødes.

Den uheldige tendens til at sætte etiketter på teorier har ført til en overbetoning af systembegrebet med efterfølgende skepsis i kraft af begrebets kolde konnotationer. System er netop en anerkendelse af, at nogle fænonener ikke lader sig skille ad i en analyse, der begriber dem som summen af delene. Netop det uigennemtrængelige er det, som bliver respekteret med forestillingen om systemer der kan referere til sig selv, psykiske såvel som sociale. Disse må derfor af en iagttager anerkendes som mere end blot objekter, der står over for subjektet. Denne respekt er også essayets grundtone.

\section{$V I$}

Man kunne overveje, hvilken forskel det gør, om man har præference for binære modsætninger eller for kontinuum. Om man er orienteret mod grænser, som Luhmann, eller mod feltet mellem en mangfoldighed af poler, som eksempelvis Bourdieu. De er dog ikke så langt fra hinanden som det kunne se ud, og deres epistemologiske overvejelser har ført dem ind $i$ en skrivefacon, der er essayistisk $i$ sin modus.

Sociologien beskæftiger sig ikke med rene former, for det står hurtigt klart, at sådanne findes ikke i den del af virkeligheden som den undersøger. Den kan simpelthen ikke have nogen ambition om at tænke essentialistisk eller substantielt. Det er måske derfor, at man finder de mest interessante systemdannelser med affilation til det essayistiske hos eksempelvis Luhmann, Bourdieu og Erving Goffman.

Nærværende er det Luhmann, der har stået i centrum, ikke mindst fordi han umiddelbart synes at være i opposition til det essayistiske, mens en anden stor skribent som Goffrnan først og fremmest er blevet opfattet som essayist. Dette har i høj grad fjernet opmærksomheden fra hans strukturalistiske og systemiske overvejelser, der har mindst ligeså stor betydning som de besnærende enkeltobservationer af eksempelvis måder at opføre sig på i elevatorer og snublende folks afværgemekanismer.

Det gør Goffman uret at læse ham sådan, på samme måde som det gør Luhmann uret at læse ham som hård systemiker. Med mindre man fortsat vil positivere den ene side i distinktionen mellem essay og system. En distinktion som ikke længere er så entydigt binær, som den historisk har præsenteret sig, hvorfor det synes stadigt sværere eller mere unødvendigt at vælge side.

For den ubesværede overgang mellem mikro- og makroplan, mellem detaljen og helheden er vel både ethvert essay og systems ideal og forhåbning. Det systematisk usystematiske fungerer bedst på en baggrund af det systemiske.

\section{Litteratur}

Bourdieu, Pierre (1997): Af praktiske grunde, København Cassirer, Ernst (1923 [1910]): Substanzbegriff und Funktionsbegriff, Berlin

Krois, John Michael (1984): Cassirer-symbolic form and history, New Haven

Luhmann, Niklas (1984): Soziale Systeme, Frankfurt/M Luhmann, Niklas (1987): Archimedes und wir, Berlin Luhmann, Niklas (1992): Beobachtungen der Moderne, Opladen

Luhmann, Niklas (1996): „A redescription of 'Romantic Art'“ in Modern Language Notes nr. 2, Baltimore 